\title{
'N AFRIKA-NOMMER VAN KOERS
}

Die Afrika-Seminaar is veel verskuldig aan die redaksie van Koers vir die gereelde publikasie van Seminaarvoordragte. In hierdie nommer word vyf referate saamgevat wat gedurende die akademiese jaar gelewer is. Hierdie beleid van Koers bied die voordeel dat die stukke bymekaar gehou en makliker nageslaan kan word. Dit beteken een Afrika-nommer van Koers elke jaar.

Hoe uiteenlopend die onderwerpe op sigself mag lyk, word hulle tog saamgebind deur die gemeenskaplike tema: Die Republiek Suid-Afrika en Afrika.

Aangesien die ontwikkelinge en veranderinge op hierdie vasteland soos elders in die wêreld, teen 'n verbysterende tempo plaasvind, word die datum waarop elke voordrag gelewer is ook aangegee.

Direkteur. 
